\title{
Intelligent Tinkering: the Endangered Species Act and Resilience
}

\author{
Melinda Harm Benson ${ }^{1}$
}

ABSTRACT. The Endangered Species Act (ESA) is one of the most powerful and controversial environmental laws in the United States. As a result of its uncompromising position against biodiversity loss, the ESA has become the primary driver of many ecological restoration efforts in the United States. This article explains why the ESA has become the impetus for so many of these efforts and assesses the strengths and weaknesses of the ESA as a primary driver from a resilience-based perspective. It argues that in order to accommodate resilience theory, several changes to ESA implementation and enforcement should be made. First and foremost, there is a need to shift management strategies from a species-centered to a systems-based approach. Chief among the shifts required will be a more integrated approach to governance that includes a willingness to reassess demands placed on ecological systems by our social systems. Building resilience will also require more proactive management efforts that support the functioning of system processes before they are endangered and on the brink of regime change. Finally, resilience thinking requires a reorientation of management away from goals associated with achieving preservation, restoration, and optimization and toward goals associated with fostering complexity and adaptive capacity.

Key Words: Endangered Species Act; governance; resilience; social-ecological systems

\section{INTRODUCTION}

"To keep every $\operatorname{cog}$ and wheel is the first precaution of intelligent tinkering" (Leopold 1949:190). This famous quote by Aldo Leopold is frequently invoked by supporters of the Endangered Species Act (ESA) (16 U.S.C. §§ 1531-1544) (Barker 1993) and for good reason. The law embodies a view of species as parts or components of a larger ecosystem that are worth saving, even when there is little understanding regarding why they might be important. One of the unintended consequences of the ESA, however, is that it has concentrated management efforts on "parts" at the expense of a more complex assessment of the resiliency of social-ecological systems (SESs). The ESA has become the primary driver of many of the large-scale ecosystem restoration efforts in the United States. Yet the law itself has limited capacity to engage the complexity of SESs. This article looks at the ESA through the lens of resilience theory. It begins with a review of the literature on resilience. It then provides a brief primer on the ESA and explains how it has become the primary driver of the environmental protection efforts in major watersheds throughout the United States. It then assesses the strengths and weaknesses of the ESA as a driver of environmental and natural resource management efforts. It concludes with some ideas for what a resilience-based approach to biodiversity loss might look like, especially in the context of climate change.

Resilience, as used in this context, describes a suite of social or ecological system properties. Holling's original (1973:17) definition explains: "resilience determines the persistence of relationships within a system and is a measure of the ability of these systems to absorb change of state variable, driving variables, and parameters, and still persist." Brand and Jax (2007) acknowledge the differing definitions of resilience that have developed since Holling's early work and point to the need for increased conceptual clarity in order to maintain the practical relevance of this concept. This study uses the definition put forward by Carpenter and others (2001), in which resilience is characterized in three ways: (1) the amount of change the system can undergo and still retain the same controls on function and structure; (2) the degree to which the system is capable of self-organization; and (3) its ability to build and increase the capacity for learning and adaptation. Within a SES, resilience reflects a system's capacity to absorb recurrent disturbances so as to retain essential structures, processes, and feedbacks. Resilience thinking acknowledges the potential for regime shifts while also providing a framework for building adaptive capacity within SESs. Within the literature in ecology, resilience has long been recognized as an aspect of sustainability (Holling 1978, Carpenter and Turner 2007).

Resilience-based management focuses on specific attributes or drivers of complex ecological systems and crafts guiding principles for human intervention to improve long-term viability of the systems (Zellmer and Gunderson 2009). Intertwined with this thinking is an acknowledgement of the adaptive cycle as a basis for understanding the dynamics of ecosystems (Garmestani et al. 2009). Adaptive management becomes the vehicle for achieving the integration of these concepts into natural resource decision making, which is why Ruhl (2008a) refers to adaptive management as the methodological sibling of ecosystem management as opposed to simply one aspect of ecosystem management (Grumbine 1994). It is important to highlight two significant aspects of resilience theory. First, resilience as a theoretical construct described in the literature is of a system. As a result, the focus is on relationships and processes within complex SESs as opposed to control or management of a single ecological 
characteristic or property (Carpenter et al. 2001). The second critical element of resilience theory is the recognition of regime change. Moving past previously held assumptions that natural systems have a single and idealized state of equilibrium, resilience thinking acknowledges disequilibrium within systems and the fact that regime shifts are often an important element of system dynamics. Panarchy is an element of resilience theory that acknowledges and provides a basis for understanding the complex interplay of system dynamics and regime change across multiple scales (Gunderson and Holling 2002).

\section{THE ENDANGERED SPECIES ACT}

The ESA is the strongest federal statute in the United States against species loss (Scott et al. 2005b, Freyfogle and Goble 2009). It was passed into law in 1973 with the ambitious purpose of providing "a means whereby the ecosystems upon which endangered species and threatened species depend may be conserved, to provide a program for the conservation of such endangered species and threatened species" (16 U.S.C. $\S 1531$ ). The ESA has become the major driver of many, if not most, large-scale biodiversity protection and habitat restoration efforts in the United States. While applicable to many terrestrial systems (perhaps most notably the Northwest Forest Management Plan and efforts to protect the Northern Spotted Owl, Strix occidentalis caurina) this is particularly true in the river restoration context. Many of these projects have formally embraced adaptive management. In Compass and Gyroscope (1993) Kai Lee documents his experiences in the ESA driven efforts to manage adaptively for both salmon and dams. On the Colorado River, adaptive management is being employed regarding the operation of Glen Canyon Dam and the flow releases necessary for the southwestern willow flycatcher (Empidonax traillii extimus), humpback chub (Gila cypha), razorback sucker (Xyrauchen texanus) and Kanab ambersnail (Oxyloma haydeni kanabensis) (Susskind et al. 2010). Similarly, adaptive management is a key strategy for CALFED Bay-Delta Program, which to a large extent is currently driven by recovery efforts of several listed species, including the delta smelt (Hypomesus transpacificus) (Norgaard et al. 2009, Booher and Innes 2010). Other examples of ESA driven programs include the Klamath Basin (Ruhl 2005, Doremus and Tarlock 2008), Platte River Restoration Program (Smith 2011), the Upper Missouri River (Davidson and Geu 2001, Tyre and Michaels 2011), the Lower Colorado River Multi-Species Conservation Program (Stern et al. 2011), and New Mexico's ESA Collaborative Program on the Middle Rio Grande (U.S. Fish and Wildlife Service 2010). While adaptive management has been embraced, it has not always been successful (Camacho 2007, Zellmer and Gunderson 2009).

To understand why the ESA is the key impetus behind these efforts, it is important to understand the basic requirements of ESA and how they operate. The key provisions of the ESA are summarized in Table 1. The main mechanism for biodiversity protection under the ESA is the placement of individual species on the official list of species that are either in danger of extinction or under the threat of becoming endangered (i.e., "threatened or endangered"). The list is maintained by the two federal agencies with the primary responsibility for ESA implementation and enforcement: the U.S. Fish and Wildlife Service for land and freshwater species and National Marine Fisheries Service for marine and anadromous species (i.e., wildlife agencies). The decision regarding whether to list a species as threatened or endangered is based on "the best scientific and commercial data available." Economic or other social factors are not considered. Listing is deemed appropriate if the continued existence of the species is threatened, and the wildlife agencies have a great amount of discretion regarding whether to list a species based on the factors listed in Table 1.

Any citizen or group of individuals can petition the appropriate wildlife agency to list a species under the ESA. In fact, most of the species currently listed receive protection as a direct result of citizen petitions. Once a petition is received, a number of enforceable deadlines fall into place, including a 90 day finding regarding whether the petition presents sufficient information to require further review, and a 12 month status review of the relevant existing scientific information to assess whether listing is warranted. If the government decides to propose the listing of a species, it then has one additional year to issue a final listing decision. The final listing decision then triggers a number of other obligations under the ESA, including the development of a recovery plan, the designation of critical habitat for the species, and a review of the listing decision every five years. In sum, a citizen petition to list a particular species sets off a cascade of duties and deadlines. During several stages of the process, the government may be challenged in court. Many of the deadlines are "hard" in the sense that, as soon as the government misses the deadline, it is in violation of the ESA and vulnerable to a lawsuit. The listing process itself is a main reason why the ESA has generated so much litigation.

Once a species is listed, a number of protections immediately fall into place. It becomes illegal to "take" a listed species, with limited exceptions. "The term "take" is broadly defined to include any actions that harm the species, including "habitat modification or degradation where it actually kills or injures wildlife by significantly impairing essential behavior patterns, including breeding, feeding, or sheltering" (50 CFR § 17.3). Listing also triggers the requirement that the appropriate wildlife agency designate critical habitat for the species either concurrently with the listing of the species or within one year of listing. Critical habitat designation becomes important in large part because the proposed adverse modification of critical habitat triggers the ESA's consultation requirement. Under Section 7 of the ESA, all federal agencies are required 
Table 1. Key Provisions of the Endangered Species Act

\begin{tabular}{|c|c|}
\hline Provision & Description and Enforceability \\
\hline $\begin{array}{l}\text { Purpose and Policy; ESA Section } 2 \text { (16 } \\
\text { U.S.C. } § 1531)\end{array}$ & $\begin{array}{l}\text { To provide: "a means whereby the ecosystems upon which endangered species and threatened species depend } \\
\text { may be conserved, to provide a program for the conservation of such endangered species and threatened } \\
\text { species." }\end{array}$ \\
\hline $\begin{array}{l}\text { Definition of "Take; Section } 3 \text { (16 U.S. } \\
\text { C. } \$ 1532 \text { ) }\end{array}$ & $\begin{array}{l}\text { "Take" is broadly defined to include any actions that harm the species, including "habitat modification or } \\
\text { degradation where it actually kills or injures wildlife by significantly impairing essential behavior patterns, } \\
\text { including breeding, feeding, or sheltering" ( } 50 \text { CFR } \S 17.3 \text { ). }\end{array}$ \\
\hline $\begin{array}{l}\text { Listing; } \\
\text { ESA Section } 4 \text { (16 U.S.C. } \S 1533(a)(1))\end{array}$ & $\begin{array}{l}\text { The listing is deemed appropriate if the continued existence of the species is jeopardized by one or more of the } \\
\text { following factors: (1) The present or threatened destruction, modification, curtailment of the species habitat or } \\
\text { range; (2) Over-utilization for commercial, recreational, scientific, or educational purposes; (3) Disease or } \\
\text { predation; (4) Inadequacy of existing regulatory mechanisms; or (5) "Other factors" affecting the species } \\
\text { continued existence (16 U.S.C. } § 1533(\mathrm{a})(1) \text { ). Several hard deadlines for acting on listing decisions. }\end{array}$ \\
\hline $\begin{array}{l}\text { Critical habitat designation; } \\
\text { ESA Sections } 3 \text { and } 4 \text { (16 U.S.C. } \S \\
\S 1532(5)(A), 1533(a)(3)(A))\end{array}$ & $\begin{array}{l}\text { "Critical habitat" is defined as: (1) specific areas within the geographical area occupied by the species at the time } \\
\text { of listing, if they contain physical or biological features essential to conservation, and those features may require } \\
\text { special management considerations or protection; and (2) specific areas outside the geographical area occupied } \\
\text { by the species if the agency determines that the area itself is essential for conservation. Economic factors } \\
\text { considered in designation. Alteration of critical habitat triggers the consultation requirement. Critical habitat } \\
\text { must be designated concurrently or within one year of decision to list the species. }\end{array}$ \\
\hline
\end{tabular}

Recovery Plans;

ESA Section 4(f)( 16 U.S.C. § 1533(f))

Recovery plans must contain: (1) objective measurable criteria for delisting the species; (2) site-specific actions; and (3) estimates of the time and cost for implementing the recovery plan.

Consultation process; ESA Section 7 (16 Requires all federal agencies to consult with the appropriate wildlife agency to ensure that their actions are not U.S. C. § 1536) likely to jeopardize the continued existence of listed species or result in destruction or adverse modification of critical habitat. Mandatory; failure to engage in consultation legally enforceable.

Prohibition Against "Take"; ESA Section 9 (16 U.S. C. § 1540)

It is illegal to "take" a listed species (see previous definition) without a permit under Sections 7 or 10 . Seldom enforced against private parties due to burden of proof issues—must show "actual injury" to listed species.

Habitat Conservation Planning and Non- Exceptions to "take" prohibition. Allows for permits for incidental take to be granted in association with the essential/experimental populations; ESA Section 10 (16 § U.S.C. 1539) development of Habitat Conservation Plans on private lands; allows for the establishment of and maintenance of experimental populations in order to facilitate recovery.

Citizen enforcement mechanism; ESA section 11 (16 § U.S.C. $1540(\mathrm{~g}))$

Subsection ( $\mathrm{g}$ ) allows any citizen to petition for listing of a species and/or compel the government to perform nondiscretionary duties under the law (e.g., engage in consultation under Section 7).

to consult with the appropriate wildlife agency to ensure that their actions are not likely to jeopardize the continued existence of listed species or result in destruction or adverse modification of critical habitat. The consultation process applies to federal actions, broadly interpreted by the courts to include not only direct construction projects but also the granting of licenses and contracts and the promulgation of regulations (Sullins 2001). Once an action agency determines that its proposed activity may affect the species, formal consultation is required and the wildlife agency issues a Biological Opinion, which includes an analysis of whether the proposed action is "likely to jeopardize the continued existence of the species" or adversely modify designated critical habitat (16 U.S. C. $\S 1536$ ). If a jeopardy determination is made, the Biological Opinion identifies any "reasonable and prudent alternatives" that would allow the action agency to move forward with the proposed activity. A Biological
Opinion includes an "Incidental Take Statement," anticipating that some take of species may result from the proposed project. The Incidental Take Statement outlines terms and conditions designed to reduce the impact of the anticipated "take" that are binding on the action agency (U.S. Fish and Wildlife Service 2007). The consultation process has become very influential and is the driving force behind the adaptive management processes described above (Benson 2008).

The ESA also provides for the development of recovery plans for listed species. Recovery plans must contain objective measurable criteria for delisting, site-specific actions, and estimates of the time and cost for implementing the recovery plan. In theory, the recovery plan functions as the central organizing tool for guiding the recovery process for each species and for implementing the ESA as a whole. In actual practice, however, the lack of easily enforceable statutory 
deadlines for developing, updating, and implementing recovery plans results in these plans having less influence than perhaps originally intended. A species is delisted if the wildlife agency determines the species is not threatened based on a number of factors, such as population size, recruitment, stability of habitat quality and quantity, and control or elimination of the threats (16 U.S.C. $\S 1533$ ). Over the years, few species have been delisted (Scott et al. 2005a, 2005b, 2010).

\section{THE ENDANGERED SPECIES ACT AND RESILIENCE THEORY}

The ESA is a relatively simple and straightforward statute. The ESA has been so influential in part because it operationalizes an uncompromising and linear process to species protection: list-protect-recover-delist (Scott et al. 2005a). The law's many legally enforceable deadlines have made it both one of the most controversial and highly litigated environmental laws in the United States. The consultation process, in particular, provides imperiled species with a seat at the table and has required a significant shift in the management focus of many large-scale federal water projects (Stern et al. 2011). In this sense, the ESA can be thought of as itself initiating regime shifts within many SESs (H. Gosnell, personal communication). The ESA driven restoration efforts noted previously are relevant examples. They each provide an example of a SES that is now grappling with the long-term consequences of its current state of water allocation and use. Without the ESA, none of these projects would likely exist. The ESA disrupted the trend of resource extraction within these watersheds and forced consideration of the consequences of these activities to the ecological systems at issue.

Viewed from the perspective of resilience theory, however, the ESA has several limitations. The first point is perhaps the most obvious. The ESA focuses on the well-being of individual species rather than overall functionality of ecological systems. While the law itself acknowledges the importance of the "ecosystems upon which endangered species and threatened species depend" the current operation of the ESA is geared toward the listing and the eventual recovery of individual species. While the wildlife agencies occasionally list several species conjunctively, success or failure of management efforts is tied to the recovery of individual species. Even the critical habitat designations for species center on the needs of individual species. This is limiting because the listed species are almost never the only component of the ecosystem in need of attention, yet the ESA focuses attention (and therefore controversy) very narrowly. The Northern Spotted Owl listing controversy in the Pacific Northwest provides an example. Controversy over protection for the owl was framed as one of "jobs vs. owls" (Kearney et al. 1999). The owl, however, served as a proxy for the forest itself and larger and more complex issues concerning the scale and pace of timber harvest and resource consumption. The use of a list of individual species as the major vehicle for biodiversity protection in the ESA reduces the focus to one of parts rather than systems, even though the threats to those species are almost always systemic.

The second limitation of the ESA relates to the fact that the law only begins to protect species when they are either threatened with or in danger of extinction. For this reason, the ESA has been referred to as an "emergency room" approach to biodiversity protection (Salzman and Thompson 2010:282). It only applies when there is specific, scientific information supporting the decision that a species is on the brink. This is problematic from a resilience standpoint for two reasons. First, the emphasis of resilience-based management is on the capacity of a system to maintain essential processes and feedbacks based on self-organization. The system is functional to the extent that it does not require intervention to maintain itself. By its very nature, an ESA listing of a species and the associated protections the species receives do not apply until management efforts to save the species are required and selforganization is either at risk or already lost. Second, because species only receive protection when they are in precipitous decline, there is often limited capacity for the level of experimentation necessary for adaptive management. While the ESA does provide for the designation of nonessential/ experimental populations of imperiled species under Section 10(j), reintroduction efforts, hatcheries, and other processes that take place under this provision are often highly regulated and limited in their flexibility.

The third major limitation of the ESA from a resilience perspective is that the ESA's main enforcement has focused largely on federal agency actions. As discussed, much of the ESA's enforcement has centered on litigation related to forcing the wildlife agencies to meet the various deadlines associated with the listing process. As a result, the primary focus of ESA implementation is often on the listing process itself. ESA management efforts are often geared toward avoiding lawsuits rather than building resilience. Furthermore, the focus on federal agency actions through the consultation process is limiting, given that private land comprises approximately $60 \%$ of land in the United States, and the percentage of important remaining habitat (for example forest lands at $72 \%$ ) is often much higher (U.S. Department of Agriculture 2001, Lubowski et al. 2002, Scott et al. 2010). As a result of the ESA enforcement and design, many of the habitat alterations that threatened species, such as land use planning decisions, are not meaningfully addressed. There has been relatively little enforcement of the "take" prohibition against private parties (Cheever and Balster 2004). Reasons include lack of political will to enforce the statute and difficulty surmounting the "proof problems" associated with meeting the "actual injury" requirement. Instead, most species protection on private lands takes place under voluntary 
agreements under the habitat conservation planning provisions of the law (Sullins 2001).

Finally, and perhaps most importantly, the ESA struggles to accommodate a resilience perspective because the law itself is based on outdated assumptions regarding ecological equilibrium and stationarity (Thrower 2006). By taking the position that extinction is not an option, it builds from an assumption that biological systems are basically stable systems comprised of a suite of unchanging variables. It does not reflect new thinking within the field of ecology regarding disequilibrium and regime change (Botkin 1990, Gunderson and Holling 2002, Folke 2006). The policies and goals of the law focus on restoration and recovery as opposed to resilience and adaptive capacity. So while legal scholars such as Robin Craig (2010) have joined ecologists in declaring that "stationarity is dead," assumptions about stationarity are alive and well in the ESA and our environmental laws. Failure to embrace the complexities associated with ecological systems, including their capacity for regime change, makes the ESA limited in terms of its capacity to address the challenges ahead, most notably the "no analog" future brought by global climate change (Ruhl 2008b).

\section{CONCLUSIONS: BEYOND COGS AND TOWARD WHEELS}

In order to accommodate resilience theory, several changes to biodiversity protection in the United States must be made. The recommendations that follow may seem dramatic, but they are achievable without congressional amendment of the ESA. While the ESA, as currently enforced, focuses on individual species, its overarching purpose is to protect not only imperiled species but also the ecosystems upon which they depend (U. S.C. $\S 1531$ (b); Blumm and Kimbrell 2004). Shifts in management paradigms are difficult, but not impossible, as evidenced in other contexts (Jarvis 2003). First and foremost, there is a need to shift our management strategies from a species-centered to a systems-based approach. Moving from a focus on specific species or even particular habitats to one that seeks to understand and better support system dynamics will allow our efforts to better capture the complexity associated with the challenges of biodiversity loss. Resilience theorists have developed models regarding the relationships between species diversity and ecological function and the distribution of function to resilience. These models have the potential to assist in unifying systems-based and speciesspecific approaches (Peterson et al. 1998, Allen et al. 1999, Allen et al. 2005).

New approaches need to allow for the formulation of meaningful responses that foster biodiversity while also increasing our understanding of the system states involved. While adaptive management is increasingly embraced by federal agencies and is now a major organizing principle for many ESA efforts (Williams et al. 2009, Stern et al. 2011), the underlying theory of resilience is also not being embraced because the law itself does not easily accommodate a resilience perspective. In general, there is a need for a better understanding of the impact of legal and institutional frameworks on adaptive management implementation. While the literature suggests that collaboratively-based, iterative processes are needed to promote flexibility and facilitate adaptation (e.g., Gunderson and Light 2006), others note that this stands in opposition to most legal requirements and processes, and that specifically enforceable standards are often preferable to open-ended guidance (Nie 2008). Adaptive management methodologies are of limited value unless they can be employed within the highly complex, often overlapping regulatory frameworks currently in place in the United States.

The second and related issue is that building resilience will require us to be more proactive in our management efforts and support the functioning of system processes before they are endangered and on the brink of regime change. As discussed, the ESA's emergency room approach has a limited capacity to meet the challenges ahead. Just as an emergency room is no place for the treatment of chronic conditions, biodiversity protection requires a more preventative strategy. Furthermore, the ESA's listing process, which takes a linear approach to species listing and management, does not accommodate the nature in which many species are and will continue to be "conservation-reliant" in the sense that maintenance of viable populations of many species will require continuing intervention (Scott et al. 2005b, 2010). In coining of the term "conservation-reliant" Scott and his colleagues $(2005 b, 2010)$ argue for a new relationship to the concept of recovery under the ESA. They suggest that viewing "recovery" as a continuum rather than as a "recovered/not recovered" dichotomy may enhance our ability to manage such species within the framework of the ESA. A resilience-based framework would also strengthen the role and authority of recovery planning as an organizational tool in this respect and move away from a linear approach to conservation.

Next, there is a need to move ESA and its enforcement beyond a focus on federal actions. For the reasons noted previously, the listing and consultation processes are important, but to focus on them almost exclusively is much too narrow. Private lands need to play a larger role in biodiversity protection. Voluntary efforts under the ESA are helpful, but without more rigorous ESA enforcement, incentives to engage in habitat conservation by private individuals will remain weak.

Finally, a resilience perspective requires a reorientation of management away from goals associated with achieving preservation, restoration, and optimization and toward goals associated with fostering complexity and adaptive capacity. As Walker and Salt (2006:141) note: "optimization (in the sense of maximizing efficiency through tight control) is a large 
part of the problem, not the solution.... When the aim is to increase the efficiency by trying to tightly control it, we usually do so at the cost of the system's resilience." Similarly, Grantham and others (2010) observe that science has generally focused on limited assessments of optimal protected area configuration. They suggest a shift to a more adaptive approach to the conservation planning process that more deliberately includes incorporating learning back into conservation design.

Restoration is often stated as a management goal (Benson and Garmestani 2011), but for most SESs, there is no "going back" to a time without water diversion, urban populations, and other continuing demands on ecological systems. The challenge of moving away from the restoration/ preservation focus is made even more necessary when confronted with the realities of climate change. The future will require us to be more intentional in assessing the role of climate change mitigation and adaptation as a means of addressing biodiversity loss. For the most part, state and federal management approaches still fail to face the reality of climate change. The ESA is perhaps the predominant example, in that it assumes recovery efforts based on historic ranges for species and does not explicitly recognize issues related to shifting habitat distributions, migration patterns, and the need for ongoing management.

In his 2008 article, Climate Change and the Endangered Species Act: Building Bridges to the No-Analog Future, Ruhl (2008b) puts forward a number of recommendations that would greatly assist in a more resilience-based approach. They include: (1) using the ESA to define and monitor the ecological reshuffling effects of climate change; (2) differentiating between species that are unlikely to survive climate change under any circumstances and those that are likely to benefit from assistance in their home ecosystems; (3) adopting an ecosystem-based management approach modeled on promoting long-term species diversity and ecosystem multifunctionality; and (4) assisted migration for species where appropriate. Questions surrounding the appropriate roles of mitigation and adaptation responses will frame the future of biodiversity protection.

Resilience thinking has the capacity to allow for a more meaningful response to these challenges, providing a conceptual basis for understanding regime change and providing a framework for building adaptive capacity. From a governance perspective, any real integration of resilience theory will require a number of changes in our approach, including new laws and institutions that better equip us to face and acknowledge that regime shifts are occurring and will continue to occur. It will also require a willingness to reassess demands placed on ecological systems by our social systems (examples: water allocation priorities and land use decisions, etc.) in recognition of the interconnectedness of SESs. Leopold's call for societies to wisely save the "parts" of the ecological systems in which they live is as relevant today as it was in 1949 when he wrote $A$ Sand County Almanac. The ESA has been an important tool in this respect. Resilience theory, however, suggests that a systems approach to biodiversity warrants a more complex, flexible, and iterative set of management tools. Not only can we do better than the ESA as an approach to biodiversity protection but we must do better. Social institutions, including legal requirements, need to change to reflect resilience theory. This includes embracing the complex, integrated, and dynamic nature of the relationship in and between SESs and changing our legal and institutional frameworks so they may benefit from resilience thinking.

"Under the statute, protections from "take" apply only to species listed as "endangered" but the U.S. Fish and Wildlife Service promulgated a rule under Section 4(d) of the statute that extends this protection to threatened species, as well. The National Marine Fisheries Services extents the take prohibition to threatened species on a case-by-case basis.

Responses to this article can be read online at: http://www.ecologyandsociety.org/issues/responses. $\mathrm{php} / 5116$

\section{Acknowledgments:}

This paper was first presented at a paper session on resilience and law at the Resilience 2011 conference in Tempe, Arizona. I am grateful to the session organizers and participants for their feedback and suggestions. I am also indebted to the anonymous reviewers of this manuscript; their insights greatly strengthened the arguments made herein.

\section{LITERATURE CITED}

Allen, C. R., E. A. Forys, and C. S. Holling. 1999. Body mass patterns predict invasions and extinctions in transforming landscapes. Ecosystems 2:114-121.

Allen, C., L. Gunderson, and A. R. Johnson. 2005. The use of discontinuities and functional groups to assess relative resilience in complex systems. Ecosystems 8:958-966. http:// dx.doi.org/10.1007/s10021-005-0147-x

Barker, R. 1993. Saving all the parts: reconciling economics and the Endangered Species Act. Island Press, Washington, D. C., USA.

Benson, R. 2008. Dams, duties, and discretion: Bureau of Reclamation water project operations and the Endangered Species Act. Columbia Journal of Environmental Law 1 (33):1-55.

Benson, M. H., and A. S. Garmestani. 2011. Can we manage for resilience? The integration of resilience thinking into 
natural resource management in the United States. Environmental Management 48(3):392-399. http://dx.doi. org/10.1007/s00267-011-9693-5

Blumm, M. C., and G. Kimbrell, G. 2004. Flies, spiders, toads, wolves and the constitutionality of the Endangered Species Act's take provision. Environmental Law 34:309-361.

Booher, D. E., and J. E. Innes. 2010. Governance for resilience: CALFED as a complex adaptive network for resource management. Ecology and Society 15(3):16. [online] URL: http://www.ecologyandsociety.org/vol15/iss3/art35/

Botkin, D. B. 1990. Discordant harmonies: a new ecology for the twenty first century. Oxford University Press, New York, USA.

Brand, F. S., and K. Jax. 2007. Focusing the meaning(s) of resilience: resilience as a descriptive concept and a boundary object. Ecology and Society 12(1):1-16. [online] URL: http:// www.ecologyandsociety.org/vol12/iss 1/art23/

Camacho, A. E. 2007. Can regulation evolve? Lessons from a study in maladaptive management. UCLA Law Review 55:293-358.

Carpenter, S. R., and M. G. Turner. 2007. A decade of ecosystems. Ecosystems 10(4):519-522. http://dx.doi. org/10.1007/s10021-007-9044-9

Carpenter, S., B. Walker, M. Anderies, and N. Abel. 2001. From metaphor to measurement: resilience of what to what? Ecosystems 4:765-781. http://dx.doi.org/10.1007/s10021-001-0045-9

Cheever, F., and Balster M. 2004. The take prohibition in Section 9 of the Endangered Species Act: contradictions, ugly ducklings, and conservation of species. Environmental Law 34:363-396.

Craig, R. K. 2010. Stationarity is dead: long live transformation: five principles for climate change adaptation law. Harvard Environmental Law Review 34:10-31.

Davidson, J. H., and T. E. Geu. 2001. The Missouri River and adaptive management: protecting ecological function and legal process. Nebraska Law Review 80:820-26.

Doremus, H., and D. Tarlock. 2008. Water war in the Klamath Basin: macho war, combat biology and dirty politics. Island Press, Washington, D. C., USA.

Folke, C. 2006. Resilience: the emergence of a perspective for social-ecological systems analyses. Global Environmental Change: Human and Policy Dimensions 16:253-267. http:// dx.doi.org/10.1016/j.gloenvcha.2006.04.002

Freyfogle, E., and D. D. Goble. 2009. Wildlife law: a primer. Island Press, Washington, D. C., USA.

Garmestani, A. S., C. R. Allen, and H. Cabezas. 2009. Panarchy, adaptive management and governance: policy options for building resilience. Nebraska Law Review 87: 1036.

Grantham, H. S., M. Bode, E. McDonald-Madden, E. T. Game, A. T. Knight, and H. P. Possingham. Effective conservation planning requires learning and adaptation. Frontiers in Ecology and the Environment 8:431-437.

Grumbine, E. 1994. What is ecosystem management? Conservation Biology 8:27-38. http://dx.doi.org/10.1046/ j.1523-1739.1994.08010027.x

Gunderson, L., and C. S. Holling. 2002. Panarchy: understanding transformations in human and natural systems. Island Press, Washington, D. C., USA.

Gunderson, L., and S. S. Light. 2006. Adaptive management and adaptive governance in the everglades ecosystem. Policy Sciences 39:323-334. http://dx.doi.org/10.1007/s11077-006-9027-2

Holling, C. S. 1973. Resilience and stability of ecological systems. Annual Review of Ecology and Systematics 4:1-23. http://dx.doi.org/10.1146/annurev.es.04.110173.000245

Holling, C. S. 1978. Adaptive environmental assessment and management. John Wiley \& Sons, London, UK.

Jarvis, J. 2003. National landscape conservation system: a new approach to conservation. USDA Forest Service Proceedings RMRS-P-27.; [online] URL: http://www.fs.fed.us/rm/pubs/ rmrs_p027/rmrs p027 110 113.pdf

Kearney, A., Bradley, G., Kaplan, R., and S. Kaplan. 1999. Stakeholder perspectives on appropriate forest management in the Pacific Northwest. Forest Science 45(1):62-73.

Lee, K. N. 1993. Compass and gyroscope. Island Press, Washington, D. C., USA.

Leopold, A. 1949. A Sand County almanac and sketches here and there. Oxford University Press, New York, USA.

Lubowski, R. N., M. Vesterby, A. Baez, and M. Roberts. 2002. Economic Research Service; Major uses of land in the United States, 2002/EIB-14. U.S. Department of Agriculture, Washintgon, D. C., USA. [online] URL: http://www.ers.usda. gov/publications/EIB14/eib14j.pdf

Nie, M. 2008. The underappreciated role of regulatory enforcement in natural resource conservation. Policy Sciences 41:139-164. http://dx.doi.org/10.1007/s11077-008-9060-4

Norgaard, R. B., G. Kallis, and M. Kiparsky. 2009. Collectively engaging complex socio-ecological systems: reenvisioning science, governance, and the California Delta. Environmental Science \& Policy 12(6):644-652. http://dx.doi. org/10.1016/j.envsci.2008.10.004

Peterson, G., C. R. Allen, and C. S. Holling. 1998. Ecological resilience, biodiversity, and scale. Ecosystems 1:6-18. http:// dx.doi.org/10.1007/s100219900002 
Ruhl, J. B. 2005. Regulation by adaptive management - is it possible? Minnesota Journal of Law, Science and Technology 7:21-57.

Ruhl, J. B. 2008a. Adaptive management for natural resources- inevitable, impossible, or both? Rocky Mountain Law Institute 54(11):§11.01.-06.

Ruhl, J. B. 2008b. Climate change and the Endangered Species Act: building bridges to the no-analog future. Boston University Law Review 88:1-62.

Salzman J., and B. Thompson 2010. Environmental Law and Policy, $3 d$ (Concepts and Insights Series). Foundation Press, Eagan, Minnesota, USA.

Scott, J. M., D. D. Goble, A. M. Haines, J. A. Wiens, and M. C. Neel. 2010. Conservation- reliant species and the future of conservation. Conservation Letters 3:91-97. http://dx.doi. org/10.1111/j.1755-263X.2010.00096.X

Scott, M., D. D. Goble, L. K. Svancara, and A. Pidgorna. 2005a. By the numbers. Pages 16-35 in D. D. Goble, J. M. Scott, and F. W. Davis. The Endangered Species Act at thirty: renewing the conservation promise. Volume 1. Island Press, Washington, D. C., USA.

Scott, J. M., D. D. Goble, J. A. Wiens, D. S. Wilcove, M. Bean, and T. Male. 2005b. Recovery of imperiled species under the Endangered Species Act: the need for a new approach. Frontiers in Ecology \& the Environment 3:383-389. http://dx. doi.org/10.1890/1540-9295(2005)003[0383:ROISUT]2.0.CO;2

Smith, C. B. 2011. Adaptive management on the central Platte River - science, engineering, and decision analysis to assist in the recovery of four species. Journal of Environmental Management 92:414-1419. http://dx.doi.org/10.1016/j. jenvman.2010.10.013

Stern, C. V., P. A. Sheikh, and C. T. Brass. 2011. Adaptive management for ecosystem restoration: analysis and issues for Congress. Congressional Research Service, Washington, D. C., USA.

Sullins, T. 2001. ESA Endangered Species Act. American Bar Association Section of Environment Energy and Resources Press, Chicago, Illinois, USA.

Susskind, L. E., A. E. Camacho, and T. Schenk. 2010. Collaborative planning and adaptive management in Glen Canyon: a cautionary tale. Columbia Journal of Environmental Law 35:2-53.

Thrower, J. 2006. Adaptive management and NEPA: how a nonequilibrium view of ecosystems mandates flexible regulation. Ecology Law Quarterly 33:871-895.
Tyre, A. J., and S. Michaels. 2011. Confronting socially generated uncertainty in adaptive management. Journal of Environmental Management 92:1365-1370. http://dx.doi. org/10.1016/j.jenvman.2010.10.014

U.S. Department of Agriculture. 2001. U.S. forest facts and historical trends. [online] URL: http://fia.fs.fed.us/library/ briefings-summaries-overviews/docs/ForestFactsMetric.pdf http:// dx.doi.org/10.1080/10576109008435851

U.S. Fish and Wildlife Service. 2010. Rio Grande silvery minnow recovery plan: first revision. [online] URL: http:// ecos.fws.gov/docs/recovery plan/022210 v2.pdf

Walker, B., and D. Salt. 2006. Resilience thinking: sustaining ecosystems and people in a changing world. Island Press, Washington, D. C., USA.

Williams, B. K., R. C. Szaro, and C. D. Shapiro. 2009. Adaptive management: the U.S. Department of the Interior technical guide. [online] URL: http://www.doi.gov/ initiatives/AdaptiveManagement/TechGuide.pdf

Zellmer, S., and L. Gunderson. 2009. Why resilience may not always be a good thing: lessons in ecosystem restoration from Glen Canyon and the Everglades. Nebraska Law Review 87:894-947. 